\title{
1,2-ADDITION OF DIMETHYL(PHENYL)SILYLLITHIUM TO CYCLIC $\alpha, \beta$-UNSATURATED KETONES AND REGIOSPECIFIC GENERATION OF CYCLIC SILYL ENOL ETHERS THROUGH BROOK REARRANGEMENT OF THE 1,2-ADDITION PRODUCTS
}

\author{
Musuto Korceda* and Sangho Koo \\ Department of Chemistry, The University of Michigan, Ann Arbor, Michigan 48109
}

Summary: A highly convenient two-step sequence for the regiospecific synthesis of cyclic silyl enol ethers has been developed involving the 1,2-addition of dimethyl(phenyl)silyllithium to cyclic $\alpha, \beta$-unsaturated ketones followed by the treatment of the resulting silyl carbinols with a catalytic amount of NaH in THF at $25^{\circ} \mathrm{C}$.

Silyl enol ethers are highly versatile intermediates on which a variety of regio- and/or stereochemically controlled synthetic manipulations can be realized. 1 Accordingly, a number of efficient methods have been developed that effect the regio- and stereochemically controlled generation of silyl enol ethers. ${ }^{12}{ }^{2}$ In $1979-80$, Kuwajima ${ }^{3}$ and Reich 4 independently established a novel Brook rearrangement-based method for the regiospecific synthesis of acyclic ( $Z$ )-silyl enol ethers (Scheme I). The origin of the exclusive formation of $Z$-isomers is attributed to the

Scheme I

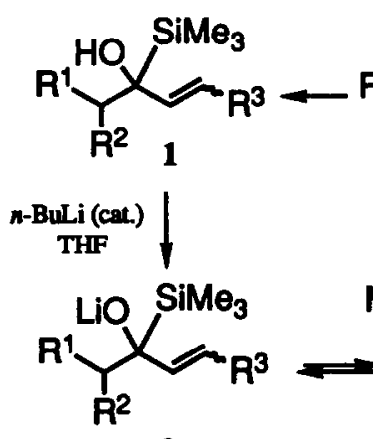

3<smiles>[R]C([R1])C(=O)O</smiles><smiles>[R]C([R])/C(=C\C=[V])O[SiH2]C</smiles>

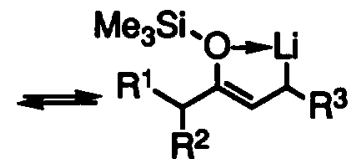

5

generation of the coondination-stabilized intermediate 5 from 4. Thus, by inference this method should not be applicable to the synthesis of most cyclic silyl enol ethers. We now report that 1,2-addition products 8 of dimethyl(phenyl)silyllithium (Me2PhSiLi) to cyclic $\alpha, \beta$-unsaturated ketones 7 can be conveniently converted regiospecifically into the corresponding cyclic silyl enol ethers 9 (Scheme II).

Trimethylsilyllithium (TMSLi) has been reported to react with cyclic $\alpha \beta$-unsaturated ketones in THF/HMPA (5:1) at $-78^{\circ} \mathrm{C}$ to give rise to 1,4 -addition products exclusively, ${ }^{5}$ whereas $\mathrm{Me} 2 \mathrm{PhSiLi}$, which can be readily formed in THF, 6 was found to undergo smooth 1,2-addition to cyclic $\alpha, \beta$-unsaturated ketones at $-23^{\circ} \mathrm{C}$ in good to excellent

Scheme II<smiles>[R2]C1=CCCC([R])C1=O</smiles>

7<smiles>[R2]C1CCCC([R12]([H])([H])C)=C1O[SiH2]c1ccccc1</smiles>

8 
Table I. 1,2-Addition of $\mathrm{Me}_{2} \mathrm{PhSiLi}$ to Cyclic $\alpha, \beta$-Unsaturated Ketones and Brook Rearrangement of the Adducts $^{\mathrm{a}}$

entry enones silyl carbinols $\%$ yield ${ }^{b} \begin{gathered}\text { conditions } \\ \text { for Brook }_{\text {rearrangement }} c \text { silyl enol ethers } \% \text { yield }^{b}\end{gathered}$

1<smiles>O=C1C=CCCC1</smiles>

2<smiles>CC1=CCCCC1=O</smiles><smiles>CC1=CCCCC1(O)Cl</smiles><smiles>CC1=CC(O)([SiH3])CCC1</smiles><smiles>CC1CCC=CC1(O)[Si]</smiles><smiles>OC1([SiH3])C=CCC1</smiles><smiles>C=C(C)C1CC=C(C)C(O)([SiH3])C1</smiles><smiles>C=C(C)C1CC=C(C)C(=O)C1</smiles><smiles>CC(C)C1CC[C@@H](C)CC1(O)Cl</smiles>

7

6<smiles>CC1=CC(=O)C(C(C)C)CC1</smiles>

89

77

A<smiles>[SiH3]C1CCCCC1</smiles>
72

89

A<smiles>CC1=C(O)CCCC1</smiles>

A<smiles>CC1C=C(OCl)CCC1</smiles>

B<smiles>CC1CCCC(O[SiH3])C1O[SiH3]</smiles>

B<smiles>[SiH3]C1CCCC1</smiles>
60

A<smiles>C=C(C)C1CCC(C)=C(O)C1</smiles>

a) Si denotes a dimethyl(phenyl)silyl group. b) Isolated yields following flash column chromatographic purification. c) Conditions: A, NaH/THF, $2 \mathrm{~h}$ at $25^{\circ} \mathrm{C}$; B, NaH/THF, $1 \mathrm{~h}$ at $25^{\circ} \mathrm{C}$; C, NaH/THF, $1 \mathrm{~h}$ at $55^{\circ} \mathrm{C}$; D. NaH/THF-HMPA (20/1), $1 \mathrm{~h}$ at $20^{\circ} \mathrm{C}$. d) $3: 2$ diastereomeric mixture. e) $\mathrm{LiCl}(0.30$ equiv) added. f) 10:1 diastereomeric mixture. g) 2:1 diastereomeric mixture. 
yields (Table 1 ). The difference in these observations may be at least partly due to the fact that the use of HMPA 7 is essential for the effective generation of TMSLi. In the case of cyclic enones with an alkyl substituent at C-6,1,2addition of $\mathrm{Me}_{2} \mathrm{PhSili}$ was found to be sluggish and the addition of a catalytic amount of $\mathrm{LiCl}$ was needed to facilitate the reaction (entries 4 and 7). Interestingly, the lithium salt produced upon 1,2-addition of Mer PhSiLi did not undergo Brook rearrangement at $-23^{\circ} \mathrm{C}$ and only the decomposition of these lithium salts was noted at higher temperatures after a few days. However, treatment of silyl carbinols 8 with a catalytic amount of $\mathrm{NaH}$ at $25^{\circ} \mathrm{C}$ in THF resulted in the facile formation of silyl enol ethers 9 by the selective protonation of the Brook rearrangement products at C-3 (Scheme II). The ${ }^{1} \mathrm{H}$ NMR analysis of the crude products indicated that the reactions are generally clean and complete within 1-2 hours without formation of an appreciable amount of side products (vields estimated from the ${ }^{1} \mathrm{H}$ NMR spectra of all of the crude Brook rearrangement products were higher than the isolated yields listed in Table I by 15-20\%). However, the reactions of the 6-substituted silyl carbinols afforded, in addition to silyl enol ethers 9, allylic silyloxy products 10 and 11 also in low yields as a result of protonation of the Brook rearrangement products at $C-1$. This appears to be a manifestation of the unfavorable $A^{1,2}$-interaction between the silyloxy group and the substituent at C-6 in silyl enol ether products 9. The effects of temperature and HMPA on this Brook rearrangement were studied next for the silyl carbinol obtained from piperitone (see entry 7). The ratio of the desired silyl enol ether and silyl allyl ether 11 was found to decrease at higher temperatures and 11 was the only isolable product when HMPA was added to the solvent. While silyl enol ethers 9 were also produced from 8 by the use of a catalytic amount of $n$-Buli instead of $\mathrm{NaH}$, the reactions were considerably less effective (40-50\% yields) and were complicated due to the formation of a substantial amount of silyl allyl ethers (see, e.g., eq. 1).<smiles>[M]C1(O)C=CCCC1</smiles>

12

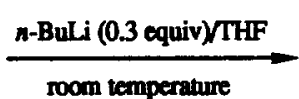

$1 \mathrm{~h}$

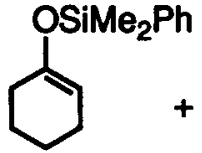

13 (51\%)<smiles>COC1C=CCCC1</smiles>

14 (7\%)

The carbanion produced by the Brook rearrangement of the alkoxide anion generated from silyl carbinol 8 with one equivalent of $n$-BuLi may be alkylated at C-3.3,4 When silyl carbinol 12 was treated with an equimolar amount of $n$-BuLi in THF at $25^{\circ} \mathrm{C}$, no Brook rearrangement product was observed upon quenching with aqueous $\mathrm{NH}_{4} \mathrm{Cl}$ at that temperature presumably because the position of the equilibrium of the two anionic species 15 and 16 lies overwhelmingly in favor of alkoxide 15. However, when the electrophile MeI was added, the alkylation reaction took place at C-3 providing 17 in $40 \%$ yield (Scheme III). It is interesting to note that when an equimolar amount

Scheme III

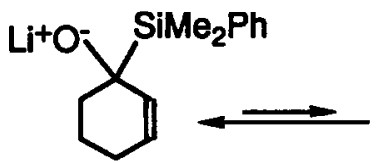

15

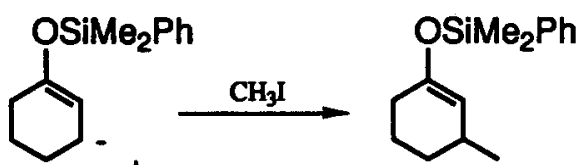

17

of $\mathrm{NaH}$ was employed for this alkylation reaction, no alkylation product was obtained. Instead silyl enol ether 13 was obtained in good yield. This is apparently due to the relatively slow formation of the sodium alkoxide with $\mathrm{NaH}$, which is protonated by the starting silyl carbinol 12 present in the reaction mixture, thus giving rise to silyl enol ether 13. 
As an application of these dimethyl(phenyl)silyl enol ethers in synthesis, the regiospecific $\mathrm{TiCl}_{4}$-catalyzed aldol reactions with benzaldehyde 8 were examined with two silyl enol ethers 18 and 19 (see eqs. 2 and 3). While these two silyl enol ethers produced the aldol products with benzaldehyde regiospecifically in comparable yields with those reported for their corresponding TMS ethers, exceptionally high erythro/threo-selectivity observed for the reaction of 18 is quite noteworthy. The erythro/threo ratio of the aldol adducts of its corresponding TMS ether with benzaldehyde was only 1:1.8 As in the case of its corresponding TMS ether (3:10:16:71), 8 silyl enol ether 19 provided a mixture of four diastereomers in a 1:17:25:57 (ax. erythro/eq. threo/eq. crythro/ax. threo) ratio.<smiles>COc1ccccc1</smiles>

18

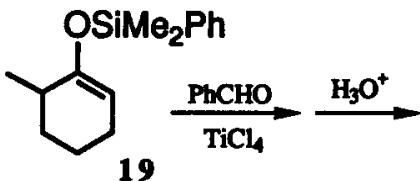<smiles></smiles>
erythro (58\%)<smiles>C[C@@H]1CCCC([C@H](O)c2ccccc2)C1=O</smiles><smiles>C[C@](O)(c1ccccc1)[C@H]1CCCCC1=O</smiles>

threo (4\%)

(66\%)

In summary, the two-step sequence delineated above offers a convenient, regiospecific means for the synthesis of dimethyl(phenyl)silyl enol ethers from their corresponding enones. 9 These silyl enol ethers can be purified through silica gel flash column chromatography and can be used for the $\mathrm{TiCl}_{4}$-catalyzed aldol reaction with aldehydes.

General Procedures for the 1,2-Addition of Me 2 PhSiLi to Cyclic $\alpha, \beta$-Unsaturated Ketones 7 and Brook Rearrangement of Silyl Carbinols 8. 7 - 8: To a stirred solution $\left(-23^{\circ} \mathrm{C}\right)$ of $0.40 \mathrm{M} \mathrm{Me} 2 \mathrm{PhSiLi}$ (1.30 equiv) in THF was added a cyclic $\alpha, \beta$-unsaturated ketone 7 (1.00 M in THF, 1.00 equiv). The mixture was stirred at $-23^{\circ} \mathrm{C}$ for $1 \mathrm{~h}$, at which point the reaction was quenched with saturated aq. $\mathrm{NH}_{4} \mathrm{Cl}$. The resulting mixture was extracted with ether twice and the combined organic extracts were washed first with saturated aq. $\mathrm{NH}_{4} \mathrm{Cl}$ and then with brine. The organic layer was dried $\left(\mathrm{MgSO}_{4}\right)$, filtered, and concentrated under reduced pressure. The crude material thus obtained was purified by flash column chromatography.

8 - 9: A catalytic amount of $\mathrm{NaH}(0.50$ equiv), which was obtained from $60 \% \mathrm{NaH}$ dispersion in mineral oil by washing twice with $10 \mathrm{~mL}$ each of hexanes, was suspended in $10 \mathrm{~mL}$ of THF. To the suspension was added a cyclic silyl carbinol $8\left(1.00 \mathrm{M}\right.$ in THF, 1.00 equiv) at $25^{\circ} \mathrm{C}$. The mixture was stirred vigorously at that temperature for 1-2 $\mathrm{h}$ and then was quenched with saturated aq. $\mathrm{NH}_{4} \mathrm{Cl}$. The resulting mixture was worked up as above.

Acknowledgment: We are grateful for the financial support of this work by the National Institutes of Health (Grant \#DK 30025). S. K. is a 1989-90 Yates Fellowship recipient.

References: 1) a) Colvin, E. W. Sillicon in Organic Synthesis; Butterworth: London, 1981. Chapter 17. b) Brownbridge, P. Synthesis 1983, 1, 85. c) Politier, J.-M. Org. Prep. Proced. Int. 1988, $20,317$.

2) For recent leading references in this area, see: a) Sakurai, H.; Miyoshi, K.; Nakadaira, Y. Tetrahedron Letr. 1977, 2671. b) Utimoto; K.; Obayashi, M.; Shishiyama, Y.; Inoue, M.; Nozaki, H. Ibid. 1980, 21, 3389. c) Negishi, E.; Chatterjee, S. Ibid. 1983, 24, 1341. d) Kraff, M. E.; Holton, R. A. Ibid. 1983, 24, 1341. e) Idem J. Org. Chem. 1984, 49, 3669. f) Tsuda, T.; Satomi, H.; Hayashi, T.; Saegusa, T. Ibid. 1987, $52,439$.

3) a) Kuwajima. I.; Kato, M. J. C. S. Chem. Commun. 1979, 708. b) Kuwajimn, L; Kato, M.; Mori, A. Tetrahedron Lett. 1980, 21, 2745.

4) a) Reich, H. J.; Rusek, J. J.; Olson, R. E. J. Am. Chem. Soc. 1979, 101, 2225. b) Reich, H. J.; Olson, R. E.; Clark, M. C. Ibid. 1980, 102, 1423.

5) a) Still, W. C. J. Org. Chem. 1976, 41, 3063. b) Still, W. C.; Mitra, A. Tetrahedron Lett. $1978,2659$.

6) Fleming, I.; Newton, T. W. J. Chem. Soc., Perkin Trans. I 1984, 1805.

7) Brown, C. A.; Yamaichi, A. J. C. S. Chem. Commun. 1979, 100.

8) Mukaiyama, T.; Banno, K.; Narasaka, K. J. Am. Chem. Soc. 1974, 96, 7503.

9) For the alternative, transition metal-catalyzed hydrosilylation of enones, see: Ojima, I; Kogure, $T$. Organometallics 1982, $1,1390$. 